\title{
A 2019-es ukrán elnökválasztás biztonságpolitikai vonzatai
}

\begin{abstract}
A tanulmány a 2019-es ukrajnai elnökválasztás kontextusában vizsgálja az Ukrajnán belüli és körüli konfliktusrendszer közeli jövőbeni alakulási lehetőségeit. Módszerként a legesélyesebb jelöltek kampányprogramjának összehasonlító jellemzését, valamint az ezekre rezonáló, feltételezhető orosz biztonságpolitikai prognózisok párhuzamba állitását alkalmazza. Alapfeltevésként abból indul ki, hogy a Majdan mozgalom és a keleti fegyveres szembenállás nyomán kialakult pillanatnyi status quót, annak lehetséges módosulásait a realista külpolitikaelméleti megközelités segítségével érthetjük meg legpontosabban.
\end{abstract}

Kulcsszavak: Ukrajna, elnökválasztás, biztonságpolitika, Porosenkó, Timosenkó, Zelenszkij

\section{Orosz Sándor: The Security Policy Consequences of the 2019 Ukrainian Presidential Election}

\begin{abstract}
This paper analyses - in the context of the 2019 presidential elections - the prospective, near future scenarios for the existing conflicts that have developed in and around Ukraine. It applies a comparative analysis of the campaign programs of the most outstanding candidates, as well as the possible Russian security prognoses in response to the results of the elections. As a basic assumption, it regards the realist international political theory as a means that helps to most precisely understand the current status quo that appeared as a consequence of the Maidan movements and the armed conflict.
\end{abstract}

Keywords: Ukraine, presidential elections, security policy, Poroshenko, Timoshenko, Zelenskiy

\section{Bevezetés}

Jelen helyzetelemzés az aktuális elnökválasztás rövid és középtávú biztonságpolitikai vonzatainak, az elörevetíthető biztonságpolitikai következményeinek vizsgálatára tesz kísérletet, végül pedig röviden kitér a feltételezhető magyar szempontokra is. A geopolitikai és biztonsági tényezőkre koncentráló részben összehasonlításra és a lehetséges párhuzamok felállítására kerül sor a jelöltek választási programjaiból kiolvasható ukrán politikai magatartás és az ebből eredő orosz előnyök-hátrányok mérlege között. Így tehát nem az elnökjelöltek közötti erőviszonyok felmérése a cél: sokkal inkább az ukrán konfliktusrendszer alakulási lehetőségeinek felmérése az esetleges győztes program és a lehetséges, erre rezonáló geopolitikai következmények összeillesztése révén. Elemzésünk alapfeltevésként kezeli az orosz szempontok, deklarált orosz államérdekek („raison d’état”) hosszú távú 
jellegét, változhatatlanságát, ezzel mintegy arra apellál, hogy a szóban forgó konfliktusrendszer, ezzel együtt pedig a Kreml külpolitikai gondolkodásmódja alapvetően a realizmus és/vagy strukturális realizmus külpolitikai elméletének logikája mentén érthető meg legpontosabban. Jelen írás végeredményben tömör elemzés felmutatására tesz kísérletet, azaz nem a konkrét eseményekből kiolvasható folyamatok, hanem a stratégiai gondolkodói szempontok szerint közelíti a kérdést.

\section{Az alaphelyzet vizsgálata: posztrevolúciós társadalmi és politikai körkép és közhangulat}

Az ukrán belpolitikában a korábbi, tehát a Majdan forradalom előtti megosztottság továbbra is megfigyelhető, mindössze annyi talán a különbség, hogy kevésbé markáns a harc a jobb-bal választóvonalak mentén, jelen aktualitások szerint sokkal inkább a jobboldali táboron belül nagy a feszültség és éles a verseny, ami viszont korábban nem volt különösebben jellemző.

A társadalmi és politikai diskurzus, egyben a politikai kampányküzdelmek legjelentősebb vitakérdései:

- a kelet-ukrán fegyveres konfliktus megoldási lehetőségei és a Krím kérdése;

- Ukrajna euroatlanti integrációs törekvései;

- gazdasági megújulás;

- kulturális (nyelvi) aszimmetria, avagy az ukrán „mesterséges” nemzetépítés ${ }^{1}$ üteme és eszközei - ukránosítás, nyelv-, oktatás- és emlékezetpolitika revideálása;

- korrupcióellenes harc, testületek;

- politikai reformok, azaz képviselői létszámcsökkentés mértéke és mikéntje a Legfelső Tanácsban, decentralizáció a régiókban, alkotmánymódosítás és kormányzási rendszer (kormányforma): parlamentáris kontra elnöki demokrácia.

Különösképpen figyelemreméltó a kulturális-nyelvi kategóriába tartozó területek kezelése, a „nemzetépítés” mint államilag irányított folyamat, ${ }^{2}$ amely a Majdan-eseményeket követően radikális ütemben felgyorsult, a 20. század első felének Európájára emlékeztető türelmetlenséggel közelítve a nyelvi és etnikai sokféleséget Ukrajnába. A Janukovics-rezsim bukása nyomán hatalomra került, önmagát mérsékeltnek, nyugati szemléletűnek, az Európai Unió demokratikus értékeit kötelező érvényünek tekintő posztrevolucionista hatalmi formáció gyakorlati lépéseiben ellent mondani látszik deklarált elveinek: figyelmen kívül hagyta az ultranacionalista félkatonai szervezetek elterjedését és működését, ${ }^{3}$ nemzetközileg egyöntetűen háborús bűnösnek, fasiszta népirtónak tekintett történelmi személyeket

Taras Kuzio: The Nation-Building Project in Ukraine and Identity: Toward a Consensus. [online]. In: Taras Kuzio Paul D’Anieri (eds.): Dilemmas of State-led Nation Building in Ukraine, Praeger, London, 2002, 9-29. o., 9. o. Forrás: chtyvo.org.ua [2019. 04. 14.]

Kuzio: $i$. m., 10.

Роман Романюк: Коррозии государсва. Куда нас заведет активность «правых», [online], 2018. 08. 10. Forrás: Pravda.com.ua [2019. 04. 14.] 
emelt törvényileg a megújuló ukrán „nemzeti panteon” csúcsára, ${ }^{4}$ illetve kötelezővé és általánossá tette heroizálásukat a közoktatásban, a szimbolikus térfoglalás jegyében országszerte köztereket, sugárutakat nevezett el róluk. Ezek összességében olyan lépések, amelyeket előzőleg csak a holokauszttagadó, ultranacionalista ukrán Szabadság Párt - amely a kilencvenes években még a "nemzetszocialista” jelzőt is viselte az elnevezésében - foglalt politikai programjába. A nemzetközi érzékenységi küszöböt is meghaladó fejleményt az EBESZ figyelmét is felkeltő oktatásügyi kerettörvény ${ }^{5}$ elfogadása képezte, ami az ukrántól eltérő nyelvű (kisebbségi) oktatást csak elemi osztályokban engedélyezi, és minden kisebbségi, így a kárpátaljai magyar tannyelvü iskolákat is gyakorlatilag a szegregáció szintjére helyezi, stigmatizálja. ${ }^{6}$ Ez utóbbi kerettörvényt az EU-s társult tagságról szóló szerződés aláíásáig nem tárgyalták, de az aláírás szinte másnapján a Legfelső Tanács napirendjére tüzték és megszavazták, ${ }^{7}$ ami arra enged következtetni, hogy a törvényalkotók és a törvényhozók tisztában voltak a tervezett szöveg EU-s elveket sértő jellegével, de pragmatikus okokból nem akarták azt a nyilvánosság elé tárni, mert így a társult tagsági státusz megszerzését sodorhatták volna veszélybe. Nem megalapozatlan azt feltételeznünk, hogy a posztrevolucionista ukrán hatalom jelen esetben visszaélt az uniós tagállamok bizalmával, azokat megvezette.

Az ukrán politikai és társadalmi diskurzusban talán soha nem látott mértékben elterjedt a nacionalista, sőt ultranacionalista hangvétel, ${ }^{8}$ értékrend, elsősorban a „méltóság forradalma" óta. ${ }^{9}$ Erre legkézenfekvőbb példaként szolgálhat a maga idejében náci karlendítéssel alkalmazott „Szlava Ukraini” köszönési forma elterjedése úgy a hétköznapokban, mint a futballmeccseken vagy az ukrán parlamentben...

Külön kutatás tárgyát képezhetné a mérsékelt értékrendek és a szélsőséges nézetek elkülönülésének hiánya a társadalmi és politikai diskurzusban, a radikális nézetek térnyerése, miközben ezek szélsőséges mivolta egyre kevésbé tudatosul, elfogadottsága folyamatosan növekszik. Ez bizonyos tekintetben a két világháború közötti európai atmoszférát idézi, ami a társadalmi, kulturális és politikai tudatosság terén fontos fejlődés alacsony lépcsőfokára utal az ukrán társadalomban. Ráadásul bizonyos jelenségek komoly aggodalomra adnak okot, mint például a paramilitáris „önkéntes” egyenruhás, kizárólag ultranacionalista színekben rivalizáló alakulatok és politikai szószólók gombamód történő elszaporodása. ${ }^{10}$

4 Порошенко підписав закон про статус учасника бойових дій для ветеранів УПА й ОУН, [online], 2018. 08. 23. Forrás: Dw.com [2019. 04. 14.]. Lásd még: Про відзначення пам’ятних дат і ювілеїв у 2019 році, [online]. Forrás: Zakon.rada.gov.ua [2019. 04. 14.]. Lásd még: Раді пропонують присвоїти Степану Бандері звання Героя України, [online], 2018. 12. 05. Forrás: Interfax.com.ua [2019. 04. 14.]

Закон України «Про освіту», [online]. Forrás: Zakon.rada.gov.ua [2019. 04. 14.]

6 Az alsó tagozatos nemzetiségi nyelvi oktatás is csak „kommunális” iskolákban lehetséges: az államnyelvü iskoláktól elkülönítve. A törvény szövege (a 7. cikkely, ill. a 13. cikkely is) különbséget tesz állami és úgynevezett „kommunális” oktatási intézmények között, ami nemzetiségi/etnikai alapú szegregáció: ez a kifejezés, fogalom nyugaton gyakorlatilag szitokszónak minősül.

7 Закон «Про освіту» прийнято - «за» проголосували 255 депутатів, [online]. 2017. 09. 05. Forrás: Mon.gov.ua [2019. 04. 14.]

8 «Слава Україні!» у війську - що збентежило західних істориків? [online]. 2018. 08. 23. Forrás: Dw.com [2019. 04. 14.]

9 Vyacheslav Likhachev: Far-right Extremism as a Threat to Ukrainian Democracy, [online]. Forrás: Freedomhouse.org [2019. 04. 14.], illetve lásd még: Summary of the Study „Extremism in Ukraine 2015-2016”, [online], 2016. 03. 03. Forrás: Uire.org.ua [2019. 04. 14.]

10 Ezek a félkatonai szervezetek akár tekinthetők egyes oligarchák „magánhadseregének” is. Lásd: Vyacheslav LIKHACHEV: Far-right Extremism as a Threat to Ukrainian Democracy. Forrás: LikHACHev: i. m. 
Fontos jellegzetesség talán, hogy voltak és vannak ugyan tüntetések elitellenes vagy korrupcióellenes hangvételben, föleg a fövárosban és a nagyvárosokban, de ezek kezdeményezői, hangadói általában nem jogaiért utcára vonuló átlagpolgárok: sokkal inkább a fent említett ultranacionalista és/vagy félkatonai szervezetek akcióiról van szó, amelyek sokszor egymás riválisai is, és szinte kivétel nélkül egy-egy konkurens politikai szereplő ellen irányulnak, nem ritkán erőszakba torkolló módon a rendfenntartó szervekkel szemben. Tehát nagy valószínüséggel nem spontán polgári kezdeményezésekről, hanem politikai és gazdasági oligarchák szembenállásának megnyilvánulásáról van szó, ${ }^{11}$ ami továbbra sem a klasszikus értelemben vett demokratikus népközpontúság ismérve: a szélesebb néprétegek szempontjai nem artikulálódnak kellő súllyal a politikumban.

További sajátosság, ami fóleg az éppen zajló kampányidőszakban vált frekventáltabbá, hogy konkrét államhatalmi szervek hajlamosságot mutatnak egy-egy adott esélyes elnökjelölttel összefüggésbe hozható korrupciógyanús tevékenység feltárására. Ez elsősorban abban nyilvánul meg, hogy az Ukrán Főügyészség és az Ukrán Titkosszolgálat (SzBU) szinte kizárólag Julia Timosenkóval, az Arszen Avakov irányítása alatt álló Belügyminisztérium pedig a regnáló államfövel szemben tesz intézkedéseket. ${ }^{12}$ Hogy ez tekinthető-e a demokratikus állammüködés, valamiféle „fékek és ellensúlyok” („checks \& balances”) funkcionális mechanizmusának, vagy ez inkább az állam diszfunkcionalitásának tünete és a hatalom kisajátítása - egy hosszabb és specifikusan erre koncentráló kutatás tárgyát képezhetné. E jelenségek kihangsúlyozása elsősorban a futó választási kampány társadalmi és politikai hangulatát hivatott érzékeltetni.

\section{Konkrét jelöletek és programok: feszültségfokozó kontra feszültséglevezető retorika}

A retorikai hangvételek pontos megértéséhez nélkülözhetetlen a politikai törésvonalak ismerete: melyek a jobb- vagy baloldaliság ismérvei, hol húzódnak a mérsékelt nacionalizmus („patriotizmus”) határai, és hol kezdődik az ukrán nemzeti radikalizmus? Ukrajna esetében mérsékelt nemzeti konzervativizmusról beszélhetünk mindaddig, amíg az eszmei keretek nem érintenek olyan ideológiákat, amelyek az ukrán mint nemzet, illetve annak kultúrája és nyelve másokhoz viszonyított felsőbbrendüségét hirdetik, ellenségként, veszélyforrásként, gyanakvóan kezelnek mindent, ami nem ukrán. Ilyen ideológia testesül meg annak a szélsőséges nemzeti eszmeiségnek a Majdan-forradalom utáni restaurációjában, amelyet eredetileg Sztepan Bandera neve fémjelez („banderizmus”). Az eredendőn mérsékeltnek, „européer”-nek indult Petro Porosenkó rendszere ezeket a határokat feloldotta, átjárhatóvá tette, jogilag kodifikálta, és mindez a kampányretorikájában csúcsosodott ki

11 В’ячеслав Шрамович: «Національні дружини”: хто і навіщо їх створив, [online], 2018. 01. 30. Forrás: BBC [2019. 04. 14.]. Lásd még: Ukraine: On patrol with the far-right National Militia - BBC Newsnight, [online], 2018. 04. Forrás: Youtube.com [2019. 04. 14.]. Lásd még: «Національні дружини»: що це за організація і чого вже встигла накоїти?, [online], 2018. 01 31. Forrás: ictv.ua [2019. 04. 14.]

12 Полиция расследует раздачу денег избирателям в офисе депутата БПП, [online], 2019. 02. 23. Forrás: Liga.net [2019. 04. 14.]. Lásd még: Тимошенко похвалила Авакова: Фальсификаций и подкупа не будет, [online], 2019.02. 22. Forrás: Liga.net [2019. 04. 14.]. Lásd még: Тимошенко назвала СБУ «провокаторами на содержании Roshen», [online], 2019. 02. 22. Forrás: Liga.net [2019. 04. 14.]. Lásd még: Аваков заявил, что у офиса Зеленского нашли прослушку: фото, [online], 2019. 03. 04. Forrás: Liga.net [2019. 04. 14.] 
leglátványosabban. Azonos táboron belüli ellenlábasa, Julia Timosenkó a nemzeti elvek tekintetében szinte azonos elveket vall: ők ketten jobbról próbálják egymást előzni. Ezzel szemben a mérsékelten jobboldali, illetve balra tartó eszmei felfogás nem helyezi mindenek fölé az ukrán nacionalizmust, nem misztifikálja az ukrán nemzeti heroizmust: Ukrajna társadalmának sokféleségében nem alá-fölé rendeltséget vizionál, a különbözőségeket egyenlőként kezeli, azokat párhuzamba állítani igyekszik. Utóbbi megközelítés tükröződik vissza Volodimir Zelenszkij vagy éppenséggel Jurij Bojkó programjában.

Megfigyelhetjük, hogy Petro Porosenkó regnáló elnök és legfőbb kihívója, Julia Timosenkó nemzeties, helyenként szélsőséges megnyilvánulásokkal tüzdelt retorikát alkalmaz. Hasonló üzeneteket fogalmaznak meg, viszont a hangsúlyok különböznek: míg Porosenkó a NATO-tagságot, tehát a katonai dimenziót teszi első helyre, addig Timosenkónál az Európai Unió követelményeinek megfelelő jogharmonizáció jelenik meg karakteresebben, kidolgozottabb (négyszáz oldal!) gazdasági tervvel ${ }^{13}$ kampányol.

A két szóban forgó versenytárs elsősorban egymás konkurense, egymást próbálják kiütni a nyeregből, azaz ugyanarra a szavazótáborra hangolnak: a jobboldali, beleértve a szélsőjobbot, de ellentmondásos módon ezzel együtt nyugatosabb kitekintésű szavazókra számítanak, kevésbé szólítják meg az egykori Régiók Pártjának szavazótáborát, vagyis a keleti és déli orosz ukránokat. Ha összeadjuk, akkor a két jelölt össz-szavazótábora megközelíti a 30\%-ot, ami azonban a konkrét jelöltek mentén élesen megosztott, jelen pillanatban Timosenkó javára.

A komikus-filmszínész, de egyben rendkívül befolyásos médiavállalati topmenedzser Zelenszkij mindkettőjükkel szemben vezet, és a legnagyobb támogatást tudhatja magáénak jelenleg a biztos szavazók körében: komoly eséllyel indul a választáson. Ö végre új szereplö, nem tartozik az országos közutálat tárgyát képező, korruptnak tekintett politikai és üzleti oligarcharéteg köreibe, de legalábbis nem hozható velük közvetlen kapcsolatba. Évtizedes és rendszeres médiaszereplései révén mégis általánosan közismert, az átlagpolgárok megítélésében igen szimpatikus és nagyon népszerü. Békés hangot alkalmaz a retorikájában a már többszörösen arcvesztett két jelölttel ellentétben, akik inkább harcias, a feszültségeket tovább élezö, a társadalmi és politikai szakadékokat tovább mélyítő, ellenségképeket vizionáló, gyakorta ultranacionalista elemeket használnak retorikájukban.

Zelenszkij programjában a kulturális és nyelvi különbségek, valamint az etnikai együttélés is természetes és türelmet, megértést igénylő jelenségek. Ellenben a nemzetiségi és nyelvi sokféleséggel szemben türelmetlenséggel, sőt dühösen fellépő ultrajobbszerü megnyilvánulásokkal, ami inkább Porosenkóra és Timosenkóra jellemző: mindketten próbálnak építeni az ultranacionalista kemény mag szavazótáborra, ami nagyon kiszélesedett a „méltóság forradalma” óta.

Pillanatnyilag azonban nyerésre áll a feszültséglevezető retorika. A „régi” szereplők egymással szemben kampányolnak, azonos táborból gyüjtenek szavazókat, miközben konkrétan a személyük mentén erősítik a (szélső)jobboldali szavazótáboron belül kitapintható szilárd törésvonalat, ezzel együtt pedig kicsi a valószínűsége, hogy híveiket felkérnék

13 Новий економічний курс України. Презентація програми, [online], 2018. 09. Forrás: Nku.com.ua [2019. 04. 14.]. Lásd még: Новий економічний курс України. Стратегія інноваційного розвитку, [online], 2018. Forrás: Nku.com. ua [2019. 04. 14.] 
a Zelenszkij elleni szavazásra, ha utóbbival kell megküzdenie a két „régi” szereplő bármelyikének a második fordulóban április második felében. Tehát egy táboron belül vannak, de kizárják egymást. Ebből Zelenszkij profitál, akkor is, ha csak korlátozottan tud elvonni szavazatokat a jobboldaliak táborából, de az ex-régiós szavazótábor ${ }^{14}$ reaktiválásával nagy létszámhoz szerez hozzáférést, szélesebbhez a posztrevolúciós nemzeties és ultranacionalista hangulatra támaszkodó „régi” szereplőknél. Ezt még a bizonytalanok rendkívül nagy táborából is bővítheti: utóbbiak körében a politikai kiábrándultság és érdektelenség igen masszív, és a Zelenszkij által kínált köztes megoldás a nacionalista szempontoktól idegenkedő, az inkább még posztszovjet nosztalgiában és melankóliában élö, föleg keleti és déli lakosság számára vonzó lehet. Választási esélyek szempontból Zelenszkij stratégiája tünik hatékonyabbnak és racionálisabbnak - figyelembe véve a pillanatnyi hangulatot és a társadalmi adottságokat. Ö sokkal kifinomultabb és szofisztikáltabb, miközben rendkívül kiszámított és patikamérlegen mért retorikai stratégiát alkalmaz, ami végeredményben akár nyerö is lehet.

\section{1. táblázat: A jelöltek esélyei százalékos arányban kifejezve a mérvadónak tekinthető közvéleménykutatások szerint ${ }^{15}$}

\begin{tabular}{|l|c|c|c|c|}
\hline & Razumkov Intézet $^{16}$ & Rating Group $^{17}$ & Socis $^{18}$ & IAP $^{19}$ \\
\hline Zelenszkij & $19,0 \%$ & $19,1 \%$ & $19,1 \%$ & $19,5 \%$ \\
\hline Porosenkó & $16,8 \%$ & $12,6 \%$ & $14,9 \%$ & $11,9 \%$ \\
\hline Timosenkó & $13,8 \%$ & $12,3 \%$ & $12,3 \%$ & $13,9 \%$ \\
\hline
\end{tabular}

Forrás: a szerző szerkesztése

A népszerütlenségi listát azonban a regnáló elnök vezeti: a Rating Group felmérései szerint a választásra jogosultak majdnem fele semmilyen körülmények között sem szavazna Porosenkóra. Ez többé-kevésbé „természetes” jelenség: az éppen hatalmon lévőknek sokszor erodálódik a népszerüsége, az elnök népszerütlensége így önmagában tehát még nem meglepö. Sokkal beszédesebb azonban az arány, a lemaradás mértéke a többi jelölthöz viszonyítva, Porosenkó ugyanis messze rosszabb e tekintetben a többieknél. Ennek egyfelöl az az oka, hogy a Porosenkó-érában az oligarchikus rendszer szinte változatlanul tovább él, ő maga nem váltotta be a korábbi politikai ígéreteit, a választók nagy része előtt hiteltelenné vált. Másfelől az ő személyével asszociálják a Majdan utáni többszörös áremelkedéseket, a súlyos inflációt, az ország külföldi eladósodását. A várakozásokkal ellentétben Ukrajna nem közeledett látványosan az Európia Unióhoz, holott ez volt a Majdan mozgalom talán

14 A Majdan-forradalom előtti Janukovics-rezsim fő szavazóbázisáról van szó, akik többségében orosz anyanyelvű lakosok az ország keleti és déli megyéiben.

15 Mind a négy forrás esetében 2019. februári mérésekről van szó.

16 Рівень довіри до суспільних інститутів та електоральні орієнтації громадян України, [online], 2019. 02. 20. Forrás: Razumkov.org.ua [2019.03.21.]

17 Моніторинг електоральних настроїв українців. Лютий 2019, [online], 2019. 03. 04. Forrás: Ratinggroup.ua [2019. 03. 21.]

18 Україна на передодні президентських виборів 2019 - лютий, [online], 2019. 02. Forrás: Socis.kiev.ua [2019. 03. 21.]

19 Електоральні орієнтації та протестні настрої українців в активній фазі передвиборчої кампанії, [online], 2019. 03. 04. Forrás: Iap.org.ua [2019. 03. 21.] 
legfontosabb gravitációs ereje. A Gallup friss felmérése ${ }^{20}$ szerint a kormány iránti bizalom indexe Ukrajnában a legalacsonyabbak egyike az egész világon: a megkérdezettek mindössze 9\%-a hisz a kormánynak.

\section{2. táblázat: A legesélyesebb jelöltek politikai nézetei a fontosabb kampánytémákban}

\begin{tabular}{|c|c|c|c|}
\hline & Porosenkó & Timosenkó & Zelenszkij \\
\hline $\begin{array}{l}\text { Doneck és Krím } \\
\text { kérdése }\end{array}$ & $\begin{array}{l}\text { A béke záloga - az erős } \\
\text { ukrán hadsereg. A had- } \\
\text { sereg, amely egyébként } \\
\text { a legjobb a világon, további } \\
\text { erősítése és fejlesztése prio- } \\
\text { ritást élvező feladat. „Had- } \\
\text { sereg, nyelv, vallás.”21 }\end{array}$ & $\begin{array}{l}\text { A területi integritás vissza- } \\
\text { állítása és a „Budapest +” } \\
\text { formátum létrehozása. } \\
\text { „A mi győzelmünk szent”, } \\
\text { „Doneck és Krím Ukrajnáé } \\
\text { mindörökre”.23 }\end{array}$ & $\begin{array}{l}\text { Nemzetközi baráti és sem- } \\
\text { leges (azaz nem NATO-s) } \\
\text { országok csapataiból } \\
\text { békefenntartó alakulatok } \\
\text { létrehozása. } \\
\text { Tárgyalásos úton kívánja } \\
\text { elérni a békét, tárgyalni } \\
\text { Moszkvával. }\end{array}$ \\
\hline EU és NATO & $\begin{array}{l}\text { Igen, létszükséglet - } \\
\text { Ukrajna úgy fog belépni } \\
\text { az EU-ba és a NATO-ba, } \\
\text { mint a térség vezető hatal- } \\
\text { ma („rehionalnij lider”). } \\
\text { EU - konkrét dátumot } \\
\text { nevez meg: } 2024 . \\
\text { Jogharmonizációt alkotmá- } \\
\text { nyos kötelezettséggé tette } \\
\text { az államhatalmi apparátus } \\
\text { minden ága számára. }\end{array}$ & $\begin{array}{l}\text { Igen, létszükség, de nem } \\
\text { jelenik meg a teljes jogú } \\
\text { EU-tagság megszerzése } \\
\text { mint stratégiai cél, a NA- } \\
\text { TO-tagság viszont igen. }\end{array}$ & $\begin{array}{l}\text { A programban egyértel- } \\
\text { műen a tagság mellet áll ki. } \\
\text { NATO - garancia Ukrajna } \\
\text { biztonságára, EU - gazda- } \\
\text { sági fejlődés. Viszont tévé- } \\
\text { interjúban elmondja: „Nem } \\
\text { fogunk oda menni, ahová } \\
\text { nem hívnak minket.” }\end{array}$ \\
\hline Gazdaság $^{24}$ & EU-tagság. & $\begin{array}{l}\text { „Új gazdaság irányvonal” } \\
\text { (Novij kurs), } 400 \text { oldal tu- } \\
\text { dományos szöveg, de nincs } \\
\text { benne egyértelmú utalás } \\
\text { EU-tagságra - nem jelenik } \\
\text { meg benne a teljes jogú } \\
\text { EU-tagság megszerzése } \\
\text { mint stratégiai cél. }\end{array}$ & $\begin{array}{l}\text { Svájci minta a példakép } \\
\text { (?): gazdasági és pénzügyi } \\
\text { vonzerő a svájci banki } \\
\text { és más szektorok mintájára } \\
\text { Ukrajnában. }\end{array}$ \\
\hline
\end{tabular}

20 World-Low 9\% of Ukrainians Confident in Government, [online], 2019. 03. 21. Forrás: Gallup.com [2019. 03. 21.]

21 Виступ Петра Порошенка на Форумі «Від Крут до Брюсселя. Ми йдемо своїм шляхом», [online], 2019. 01.29. Forrás: Youtube.com [2019. 03. 21.]

22 Дмитрий БОБРИЦКИЙ: Она идет! 10 вещей со съезда Тимошенко, которые нас удивили, [online], 2019. 01.23. Forrás: Liga.net [2019. 03. 21.]

23 Новий курс України. Нові можливості для кожного, [online], 2019. Forrás: Liga.net [2019. 03. 21.]. Lásd még itt: Правила кандидатства Юлии Тимошенко [online], 2019. Forrás: Liga.net [2019. 03. 21.]

24 Юрий Смирнов: Заживем по-людски. Как топ-кандидаты обещают поднять экономику, [online], 2019. 02.14. Forrás: Liga.net [2019. 03. 21.] 


\begin{tabular}{|c|c|c|c|}
\hline & Porosenkó & Timosenkó & Zelenszkij \\
\hline $\begin{array}{l}\text { Szociális és kulturá- } \\
\text { lis kérdések }\end{array}$ & „Hadsereg, nyelv, vallás.” & $\begin{array}{l}\text { Oktatási reform, amit } \\
\text { a programjában részletez. }^{25}\end{array}$ & $\begin{array}{l}\text { Tévéinterjúban kifejti, hogy } \\
\text { az ukrán kötelező állam- } \\
\text { nyelv, de általánossá tétele } \\
\text { csak fokozatosan történ- } \\
\text { het, nem lehet rövid távon } \\
\text { megtanítani mindenkivel. }\end{array}$ \\
\hline $\begin{array}{l}\text { Korrupció elleni } \\
\text { harc }^{26}\end{array}$ & $\begin{array}{l}\text { Korrupcióellenes Testület } \\
\text { a jó eszköz a korrupció } \\
\text { elleni küzdelemben, ez már } \\
\text { elegendő, nem szükséges } \\
\text { tovább szélesíteni az intéz- } \\
\text { ményesített antikorrupciós } \\
\text { tevékenységet. }\end{array}$ & $\begin{array}{l}\text { Alkotmánymódosítással, } \\
\text { azaz egész pontosan telje- } \\
\text { sen új alkotmány elfogadá- } \\
\text { sával küzdeni a korrupció } \\
\text { ellen. }\end{array}$ & $\begin{array}{l}\text { Kiegyezés az oligarchákkal: } \\
\text { új időszámítást - mostantól } \\
\text { kezdve egyezzenek bele } \\
\text { a tiszta üzletbe és a tisz- } \\
\text { tességes adózásba, cserébe } \\
\text { nincs ellenörzés vissza- } \\
\text { menő hatállyal az eddigi } \\
\text { vagyonosodások forrásait } \\
\text { és mechanizmusait illetően. }\end{array}$ \\
\hline Politikai reformok ${ }^{27}$ & $\begin{array}{l}\text { Elnöki jogkörök fenn- } \\
\text { tartása. }\end{array}$ & $\begin{array}{l}\text { Parlamentáris köztársaság }{ }^{28} \\
\text { és teljesen új alkotmány, } \\
\text { képviselői mentesség el- } \\
\text { törlése. }\end{array}$ & $\begin{array}{l}\text { Parlamentáris köztársaság } \\
\text { bevezetése. }\end{array}$ \\
\hline
\end{tabular}

Forrás: a szerző szerkesztése

\section{Geopolitikai összefüggések és biztonságpolitikai szempontok}

Amennyiben elfogadjuk igaznak Vladimir Horbulin megállapítását, ${ }^{29}$ miszerint Ukrajna a 21. században újra a nagyhatalmi játszmák eszközévé vált, úgy az ukrán konfliktusrendszert a Krímmel, Doneckkel, sőt talán a Majdan-forradalommal együttesen, egymással szoros összefüggésben kell kezelnünk. Nézőpontjával azonosulhatunk, amennyiben belátjuk, hogy Ukrajna önerőből, azaz nyugati pénzügyi és politikai-diplomáciai támogatás nélkül a realizmus értelmezése szerinti önsegély („self-help”) elvének érvényre juttatására kevésbé látványosan - vagy egyáltalán nem - lehetett volna képes az orosz nyomással szemben az elmúlt években. Horbulin megállapításából az is következik, hogy egy ilyen kontextusban Ukrajna nem független tényező, nem önálló szereplője a történéseknek és nincs önálló és számottevő ráhatása az esetleges végkifejletre: csupán passzív szenvedő alany, ha úgy tetszik, egy proxyháború, azaz köztes háború egyszerű terepe. Egy olyan közvetítő színtér, amely révén a föszereplő nagyhatalmak a valóságos küzdelmet nem közvetlenül egymással konfrontálódva, hanem közvetett módon, befolyási övezeteik mozgatása révén vívják meg. Könnyü belátni, hogy ez nem példa nélküli a diplomáciatörténelemben.

25 Урочистий з’їзд Всеукраїнського об’єднання «Батьківщина», [online], 2019. 01. 22. Forrás: liga.net [2019. 03. 21.]

26 Юрий Смирнов: Казнить взяточников! Как топ-кандидаты обещают побороть коррупцию, [online], 2019.02. 07. Forrás: Liga.net [2019. 03. 21.]

27 Роман Супрун: Поделить и под суд: как кандидаты в президенты видят реформу Рады, [online], 2019. 02. 21. Forrás: Liga.net [2019. 03. 21.]

28 «В штабе Порошенко новая фантазия». Интервью Авакова - за минуту, [online], 2019. 02. 23. Forrás: Liga.net [2019. 03. 21.]

29 Володимир Горбулін: Збройний конфлікт в Україні у термінах геополітики, [online], 2016. Forrás: Nbuv.gov.ua/ [2019. 03. 21.] 
Mielőtt kísérletet teszünk megfejteni azt, hogy a küszöbön álló ukrán elnökválasztás milyen hatással lehet a fenti feltételezett geopolitikai konjunktúrára, fontos megvizsgálnunk az orosz szempontot, föleg amennyiben Oroszországot elfogadjuk a Horbulin által feltételezett geopolitikai játszma egyik nagyhatalmi föszereplőjének. Orosz oldalon az analitikusok szintjén geopolitikai összefüggésekben, 5-10 évnyi időtartamú „prognózisokban” gondolkodnak. ${ }^{30}$ A szerzők írásukban abból indulnak ki, hogy orosz szempontból kedvezően vagy kedvezőtlenül alakul a helyzet az ukrán konfliktusrendszer ügyében, ennek megfelelően két feltételezést készítettek. A szerzők minden jel szerint szintén evidenciának tekintik, hogy Ukrajna kiemelkedő fontosságú érdekszféra Oroszország számára, ha úgy tetszik, a befolyás megerősítése prioritást élvező orosz állami (nemzeti) érdek, amit történelmi, kulturális, de mindenekelőtt biztonságpolitikai szempontok mentén magyaráznak. Ha abból az elemzői megközelítésből indulunk ki, hogy az ukrán konfliktusrendszer a legújabb „befagyott posztszovjet konfliktus” megnyilvánulása, amelyet elsősorban orosz politikai és katonai aktivitás hoz létre, akkor a legfontosabb külső befolyásoló tényezönek Oroszország ambícióit és további lépéseit vehetjük. Elenyésző a tévedés rizikófaktora, ha azt feltételezzük, hogy a Kreml a befagyott állapot fenntartásában, vagyis a konfliktus intenzitásának egy viszonylag alacsony, mégis állandósult szinten való konzerválásában, esetleg időnkénti fokozásában érdekelt addig, amíg az Ukrajnához füződő érdekeit érvényesíthetőnek véli.

Fontos azonban leszögezni, hogy Ukrajna irányában egyetlen más meghatározó szereplőnek, elsősorban az Európai Uniónak, illetve egyes tagállamainak, sem pedig az Egyesült Államoknak nincsenek olyan állami vagy nemzeti érdekei, amelyeket akár nagy áldozatok révén (például fegyveres beavatkozás) is készek lennének érvényesíteni. Ezzel szemben Oroszország folyamatosan kiemelt állami érdekeire hivatkozik, nemcsak biztonsági és gazdasági, de történelmi-kulturális hagyományokra, alapvető ideológiai kérdésekre, amiből arra lehet következtetni, hogy Ukrajnát egy egységes keleti szláv hatalmi-kulturális tér integráns részének, más szóval orosz befolyási övezetnek tekinti. ${ }^{31}$ Ilyen mélységü érdekek artikulálása esetén nem feltételezhető, hogy az orosz szempontok a belátható időn belül külső vagy bármilyen más hatásra megváltoznak, sokkal valószínübb a kitartó önérdekkövető lépések megtétele a Kreml részéről.

30 В. И. Гришин - А. П. Кошкин - И. В. Бочарников - В. В. Черданцев: Безопасность и интересы России в условиях украинского кризиса: анализ и прогнозы, [online], 2015, ФГБОУ ВПО «РЭУ им. Г. В. Плеханова». Forrás: Rea.ru [2019. 03. 21.]

31 Обращение президента России В. В. Путина 18 марта 2014 года к обеим палатам Федерального собрания: „И наша обеспокоенность понятна, ведь мы не просто близкие соседи, мы фактически, как я уже много раз говорил, один народ. Киев - мать городов русских. Древняя Русь - это наш общий исток, мы всё равно не сможем друг без друга.” Részlet Vlagyimir Putyin, Oroszország Elnöke a Szövetségi Gyülés két kamarájához intézett 2014. március 18-i beszédéből: „A mi aggodalmunk is indokolt, ugyanis mi (Oroszország és Ukrajna, a szerző) nem csupán jószomszédok vagyunk, hanem ahogy azt már olyan sokszor említettem, mi gyakorlatilag azonos nép vagyunk. Kijev az orosz városok szülőanyja, az Ösi Rusz pedig a mi közös eredetünk, ezért nem létezhetünk egymás nélkül." [online], 2014. 04. 18. Forrás: Kremlin.ru [2019. 03. 21.] 
Ráadásul, amennyiben elfogadjuk, hogy az orosz stratégia a politikai realizmus alapjain nyugszik, úgy komolyan kell vennünk az orosz elemzők Oroszország feltételezett külpolitikai „szövetségeseiről” megfogalmazott gondolatát: nem állnak ki határozottan Moszkva mellett, ${ }^{32}$ így Oroszországnak nem marad más választása, mint érvényre juttatni az önsegély („,self-help”) realista alapelvét. Ez azt jelenti, hogy szövetségesekre csak korlátozottan vagy egyáltalán nem számíthat, önerőből kell megvédenie az érdekeit. Ismerve az orosz álláspont merevségét, ez a Kremlt minden bizonnyal tovább erősíti a saját maga által kijelölt stratégiai irányvonal fenntartásában.

Ha részletesen megvizsgáljuk a fent megnevezett három esélyes elnökjelölt politikai programját és az orosz elemzők (stratégák) által felvázolt elképzeléseket, akkor azt találjuk, hogy van bizonyos „megfeleltethetőség” a programok és az elképzelések között. Azt figyelhetjük meg, hogy az orosz szempontból negatív kimenetelü fejlődési menetrendek inkább állnak párhuzamban a jobboldali jelöltek programjával, azaz a jobbra tartó Porosenkó és Timosenkó szemléletrendszere az orosz érdekek szerint hátrányos. Vagyis bármelyikük hatalomra jutása esetén Oroszországnak 5-10 éves időtávon negatív és elutasító külső környezetre, Oroszországgal ellenséges ukrán és nyugati kül- és biztonságpolitikai magatartásra, elhúzódó konfliktusra kell számítania.

Az orosz szempontból pozitív forgatókönyvet a kevésbé (szélsőségesen) jobboldali és/ vagy a határozottan balra tartó jelöltek valamelyikének győzelme jelenthetné, a Kreml számára kedvezőbb konjunkturális változást egy ilyen elnök megválasztása hozhatja el. Közülük a már említett Volodimir Zelenszkij és Jurij Bojkó nevezhető meg. Népszerüségi index tekintetében őket követi (7-8\%-os támogatottsággal) Anatolij Hricenkó. Ö azonban szélsőjobb irányba tart: pártjának politikai programja az ukrán etnikum jogi értelemben vett privilegizálását, ezzel együtt pedig a többi etnikai csoport ehhez képest viszonylagos (korlátozott?) jogi reprezentációját, ezzel együtt pedig az ukrán politikai nemzet létrehozását irányozza elő. ${ }^{33}$

Alábbi táblázat összegzi, mire számíthat Moszkva egyik vagy másik elnökjelölt hatalomra jutása esetén. A jobboldali oszlopban az „A” jelöli az orosz szempontból kedvező, míg a „B” a kedvezőtlen várakozásokat.

32 В. И. Гришин - А. П. Кошкин - И. В. Бочарников - В. В. Черданцев: i. m.

33 Amennyiben ez sorrendiség felállítását jelenti, ezzel korábban az ukrán Szabadságpárt (Szvoboda) kampányolt. Nem épp a nyugati értelemben vett demokratikus egyenlőség alapeleme. Idézet Anatolij Hricenkó választási kampányporgramjából: „Утвердження інституту громадянства України як пріоритетного по відношенню до національних і етнічних груп населення - формування політичної націï”. Magyar fordításban: „Az ukrán állampolgárság előjogainak beerősítése a többi nemzetiséghez és etnikumhoz képest és az ukrán politikai nemzet megteremtése." Програма політичної партії «Громадянська позиція», [online], 2018. Forrás: Rea.ru [2019. 03. 21.] 
3. táblázat: Orosz geopolitikai várakozások összevetése az ukrán elnökválasztás lehetséges verzióival

\begin{tabular}{|c|c|c|}
\hline & Ukrán elnökválasztás kimenetele & Orosz prognózisok \\
\hline \multirow[t]{2}{*}{ Ukrajna } & $\begin{array}{l}\text { A - Békerendezés tárgyalásos úton, nem } \\
\text { fegyverek révén történik. Legfeljebb sem- } \\
\text { leges és baráti (nem NATO-tag) országok } \\
\text { katonáiból álló békefenntartó alakulatok le- } \\
\text { hetnének jelen a konfliktuszónában. Ez egy } \\
\text { mérsékelten jobboldali (Zelenszkij) vagy } \\
\text { balra tartó (Jurij Bojkó) jelölt győzelme ese- } \\
\text { tén értelmezhető. }\end{array}$ & $\begin{array}{l}\text { A - Oroszország megőrzi és megerősíti } \\
\text { befolyását Ukrajna felett (talán még } \\
\text { a „Novorosszija” projekt is sikerrel jár). }\end{array}$ \\
\hline & $\begin{array}{l}\text { B - Doneck és Krím visszaszerzése - ka- } \\
\text { tonai úton (Porosenkó) vagy nemzetközi } \\
\text { nagyhatalmi garanciák révén (Timosenkó). } \\
\text { Porosenkó: „A béke záloga az erős ukrán } \\
\text { hadsereg.” } \\
\text { Ukrajna belép a NATO-ba, méghozzá ve- } \\
\text { zető regionális középhatalomként (Poro- } \\
\text { senkó). } \\
\text { Porosenkó vagy Timosenkó, azaz valame- } \\
\text { lyik esélyes (szélső)jobboldali elnökjelölt } \\
\text { győzelme esetén valósulhat meg. }\end{array}$ & $\begin{array}{l}\text { B - Az orosz befolyás („terjeszkedés”) } \\
\text { ellehetetlenül, Ukrajna élesen orosz- } \\
\text { ellenessé válik, talán betagozódik } \\
\text { az euroatlanti integrációs folyamatokba, } \\
\text { minimum társult tagként (NATO-ba } \\
\text { is). Általánossá válik az ukrán naciona- } \\
\text { lizmus („neobanderizmus”). Visszacsa- } \\
\text { tolják Donecket területi autonómiával, } \\
\text { amelyet később eltörölnek, majd Krímet } \\
\text { veszik célba, és a nyugati szövetségesek- } \\
\text { kel együtt fokozzák az Oroszországra } \\
\text { gyakorolt nyomást. }\end{array}$ \\
\hline \multirow[t]{2}{*}{ Nyugat-Európa/EU } & $\begin{array}{l}\text { A - EU-tagság megszerzése érdekében tett } \\
\text { lépések folytatása, de ezzel együtt kiter- } \\
\text { jedt gazdasági, kereskedelmi, energetikai } \\
\text { kapcsolatok fenntartása Oroszországgal } \\
\text { és az eurázsiai térséggel. Ez a szcenárió bal- } \\
\text { oldali jelöltek választási programjára jellem- } \\
\text { zö, elsősorban Zelenszkijt lehet megnevezni. }\end{array}$ & $\begin{array}{l}\text { A - Európa orosz forrásokból történő } \\
\text { energetikai ellátásának kitettsége nem } \\
\text { csökken, így Oroszország befolyásolási } \\
\text { esélyei az EU-ra energetikai értelemben } \\
\text { megmaradnak. }\end{array}$ \\
\hline & $\begin{array}{l}\text { B - Teljes jogú EU-tagság megszerzése és tá- } \\
\text { volodás Oroszországtól gazdasági és ener- } \\
\text { getikai téren. Ez inkább jobboldali jelöltek } \\
\text { választási programja: Porosenkó és Timo- } \\
\text { senkó. }\end{array}$ & $\begin{array}{l}\text { B - Az EU fokozza az Oroszországra } \\
\text { gyakorolt nyomást (pl. szankciók) } \\
\text { az ukrajnai helyzet miatt. Az EU a fe- } \\
\text { lelösséget egyoldalúan a „civilizáci- } \\
\text { ós” értelemben vesztes félre hárítja, } \\
\text { ezzel együtt minden ukrán félkatonai } \\
\text { és egyéb, Kijevből központilag irányított } \\
\text { igazságtalanság fölött szemet hunynak. } \\
\text { Ukrajna közeledik az EU-hoz. }\end{array}$ \\
\hline
\end{tabular}




\begin{tabular}{|l|l|l|}
\hline Egyesült Államok & \multicolumn{1}{|c|}{ Ukrán elnökválasztás kimenetele } & \multicolumn{1}{c|}{ Orosz prognózisok } \\
\hline & $\begin{array}{l}\text { A - Legfeljebb társult NATO-tagság vagy } \\
\text { különleges szövetségesi, együttmüködési } \\
\text { státus megszerzése. Esetleg mindössze alkal- } \\
\text { mi katonai vagy specifikus hadiipari együtt- } \\
\text { működés egyes NATO-tagországokkal, } \\
\text { amolyan „szatellit” jelleggel. Ez balra tartó } \\
\text { program érvényesülése esetén lehetséges. }\end{array}$ & $\begin{array}{l}\text { A - USA részlegesen vagy teljesen } \\
\text { kihátrál Ukrajna mögül, az orosz tér- } \\
\text { nyerés fokozódik, és Moszkva revizio- } \\
\text { nista kísérletei a posztszovjet térség } \\
\text { feletti befolyás újjászervezésére immár } \\
\text { akadálymentessé válnak. }\end{array}$ \\
\cline { 2 - 3 } & $\begin{array}{l}\text { B - Ukrajna csatlakozása a NATO-hoz, illet- } \\
\text { ve eléri nagyhatalmi garanciák kieszközlését } \\
\text { a területi integritás visszaállítása érdekében. } \\
\text { Ez jobboldali jelöltek választási programjára } \\
\text { jellemző: Porosenkó és Timosenkó. }\end{array}$ & $\begin{array}{l}\text { B - USA növeli a szankciós és más } \\
\text { típusú - pl. katonai erődemonstráci- } \\
\text { ón - nyomást Oroszországra Ukrajna } \\
\text { miatt és Ukrajna révén. }\end{array}$ \\
\hline
\end{tabular}

Forrás: a szerző szerkesztése

A fenti összevetés szemlélteti többek között azt is, hogy milyen esetekben számíthatunk az ukrán konfliktusrendszer kapcsán kialakult nemzetközi feszültség intenzitásának fokozódására vagy enyhülésére a következő elnöki ciklusban. Ha a katonai dimenziót kevésbé hangsúlyozó, helyette a tárgyalásos megoldáskeresést preferáló elnök kerül hatalomra, az fokozatos szemléletmódosulást - nem váltást - eredményezhet az ukrán álláspontban, „felpuhulhat” a kemény harcias retorika. A Porosenkó elnök évértékelő beszédében elhangzott érvek értelmében a Nyugat figyelme Ukrajna felé nem magától értetődő dolog: a külügy nagyon komoly lobbitevékenységet fejt ki a támogatás érdekében. ${ }^{34}$ Viszont egy kevésbé jobboldali elnök megválasztásával csökkenhet az ukrán diplomácia nyugati támogatás fenntartására irányuló erőfeszítéseinek intenzitása, ezzel arányosan csökkenhet a Nyugat figyelme az ukrán konfliktusrendszer felé. Egy ilyen diplomáciai „súlypont-áthelyeződés" fontos lehet abban az esetben, ha ehhez hozzá adódik, hogy a májusban esedékes Európai Parlamenti választások során a jobb és szélsőjobb erők esetlegesen növelik a mandátumaik számát, és ezzel fokozódik a Moszkvával szembeni szankciók enyhítésére irányuló lobbitevékenység az Európai Unió parlamentjében. Ez elősegítheti egy fokozatos „enyhülés” létrejöttét az Oroszország körül kialakult feszült nemzetközi atmoszférában, akár a szankciós politika is megváltozhat. Összességében csökkenhet a biztonsági fenyegetettség(érzet) Európában. Amennyiben azonban jobboldali jelölt nyeri az elnökválasztás, úgy miden jel szerint a jelenlegi kemény álláspont marad érvényben az ukrán bel- és külpolitikában, sőt akár fokozódhat is, a nyugati támogatás és figyelem fenntartása is kulcskérdés marad. Egy ilyen prognózis szerint a jelenlegi konfliktus elhúzódhat, a megoldás pedig időben kitolódik, a közeli jövőben nem talál erre kompromisszumot a nemzetközi közösség, így az európai biztonsági kockázatok sem enyhülnek: a biztonságra fordított kiadások, a biztonság „ára” magas marad vagy akár növekedhet is.

34 За підтримку Заходу треба боротися щодня - президент, [online], 2018. 09. 20., Dzerkalo Nedeli. Forrás: Dt.ua [2019. 03. 21.] 


\section{Magyar szempontok}

Magyarország kormánya 2010 óta intenzíven támogatja a kárpátaljai magyarság szülőföldön való megmaradását és boldogulását: a kulturális mellett kiterjedt gazdasági projektek valósulnak meg, a magyar állampolgárság (könnyített visszahonosítás) pedig Kárpátaljaszerte rendkívül népszerủvé vált, a magyar nyelv presztízse exponenciálisan emelkedett a helyi lakosság körében, beleértve az elsősorban szláv anyanyelvü állampolgárokat is. A lakosság alapvetően kedvezően fogadta a jelenséget, azonban a Majdan-forradalmat követően hatalomra került ukrán nemzetépítő, az ukrán nyelv és identitás általánossá tételtét, az egységes ukrán információs tér kialakítását nemzetbiztonsági ügyként kezelő új kijevi kormány veszélyforrásként, szeparatizmus megnyilvánulásaként, a terület feletti szuverenitásának megsértéseként érzékelte a kialakult helyzetet. Magyarország külpolitikájában a Kijev szempontjából törvényileg is agresszornak nyilvánított Oroszország fontos baráti szerepet kapott, az ellenkező irányba mutató nemzetközi tendenciák dacára. Ez tovább fokozta a gyanút a kijevi vezetésben, de a magyar-ukrán viszony valójában az ukrán oktatásügyi kerettörvény elfogadásával egycsapásra elmérgesedett, azóta a helyzet fokozatosan romlik. Jóllehet az utóbbi kérdés kapcsán nemzetközi szervezetek, mint például az EBESZ vagy a NATO a magyar álláspont védelmében szólaltak fel, ${ }^{35} \mathrm{Kijev}$ kizárólag a saját szempontjából, statikusan, reálpolitikai önérdekkövető módon közelíti a kérdést.

Mindezekkel egy időben sem Ukrajnában, sem körülötte nem enyhül a nemzetközi feszültség, így könnyü belátni, hogy egy bizonytalan biztonsági helyzet hosszú távú fennmaradása Magyarország biztonsággal kapcsolatos kiadásait is növelné az elkövetkezö években, a biztonságérzetet csökkentené. Értelemszerüen magyar szempontból az Ukrajnán belüli és körüli feszültség enyhülése kulcsfontosságú. Budapest és Kijev között mindeddig példa nélküli módon felfokozódtak az ellentétek, amit egyik oldalon az ukrán politikai irányvonal éles jobbratolódása (a Majdan-forradalmat követően) idézett elő, másrészről pedig okoz(hat)ta ezt Magyarország kárpátaljai magyarok támogatására irányuló politikája vagy legalábbis annak gyanakvással teli fogadtatása a kijevi nemzetépítő politika szempontjából. Jobboldali jelölt győzelme esetén egy nemzetvédö, a kisebbségekkel (és azok nyelvhasználatával) szemben gyanakvó és türelmetlen irányvonal erősödése, azaz Ukrajna még a jelenleginél is erősebb jobbra tolódása prognosztizálható. Ez esetben Magyarország nem számíthat a Budapest-Kijev viszony javulására, hanem épp ellenkezőleg, annak további fokozódására, ami a kormánynak a külhoni magyarságot erősíteni szándékozó lépéseit tovább nehezítheti. A kétoldalú kapcsolatok javulása valószínüsíthető egy baloldali jelölt győzelme esetén. Erre megvan az esély, legalábbis amennyiben megbízhatunk a fenti népszerüségi mutatóknak.

Ezzel együtt a kárpátaljai magyar érdekvédelem szemszögéből végeredményben nem - vagy nem csak - az elnökválasztás a fontos: az öszi parlamenti választás vélhetően fontosabb lesz. A helyi magyar közösség az ukrán nagypolitikában csak a Legfelső

\footnotetext{
35 A NATO szolidáris Magyarországgal a (vitatott) ukrán oktatási törvény ügyében. НАТО солідарне з Угорщиною щодо українського закону про освіту, [online], 2019. 02. 26. Forrás: Dw.com [2019. 03. 21.]
} 
Tanácsban tudja képviseltetni magát, fontos, hogy kormánykoalíciós párt színeiben jusson be kárpátaljai magyar képviselö az ukrán parlamentbe. Az elnöki pozíció és az elnök személye nincs közvetlen kapcsolatban a helyi kisebbséget érintő kérdésekkel, egy pártpolitikai betagozódás viszont igen. Ennek ráadásul kiemelkedő fontossága lehet, amennyiben az új elnök politikai reform témakörben parlamentáris demokráciát, azaz nem prezidenciális vagy félprezidenciális kormányzási rendszert hoz létre, mert így a pártpolitikai érdekek könnyebben érvényesülhetnek parlamenti szavazás révén. Persze nincs és nem is lehet biztos garancia arra, hogy egy adott pártszövetség ukrán fele, ha kormányra kerül, a parlamentben mindig olyan kérdéseket fog preferálni, amelyek a kárpátaljai és adott esetben Budapest érdekeivel egybeesnek, lévén a pillanatnyi ukrán érdekek adott érdekcsoportokon belül rendkívül képlékenyek, érdekfolytonosságról ritkán beszélhetünk, vagy ha igen, akkor az magyar szempontból vállalhatatlan.

\section{Következtetések}

A Majdan-forradalom előtti megosztottság továbbra is érvényes, azzal a fontos különbséggel, hogy jelen aktualitások szerint a jobboldali táboron belül nagy a türelmetlenség a rivális jelöltek között. A legesélyesebb jelöltek választási programjaiból kiolvasható, a választást követő időszakra várható ukrán politikai magatartás lehet jobboldali nacionalista, helyenként szélsőségek felé tartó konstruktív elemekkel, vagy lehet mérsékelten jobboldali, óvatos balratolódással. Az ukrán konfliktusrendszer alakulási lehetőségei, illetve a feltételezhető geo- és biztonságpolitikai következmények vonatkozásában a különbség lehet nagyon számottevő is: 1. Ukrajna tovább haladhat egy határozottan nacionalista, sőt, keményvonalas szélsőséges politikai irányba, vagy 2 . lelassulhat az „erőltetett menetben” mozgó nemzetépítés, ami több elemében is a bipoláris nemzetközi rendszer elötti korszakra emlékeztet. Előbbi esetben kelet-ukrajnai konfliktus és az ekörül kialakult nemzetközi bizonytalanság stagnálhat vagy fokozódhat - a békés megoldás perspektívája nélkül. Második esetben azonban ennek sok tekintetben az ellenkezője prognosztizálható: mérséklődhet a nezeties(kedő) hangvétel, oldódhat a belső és a külső feszültség, ami akár párbeszéd megindítására is alkalmas atmoszférát alakíthat ki.

Azonban, ha abból indulunk ki, hogy Ukrajna a 21. században a nagyhatalmi játszmák eszközévé vált, azaz nem független tényezö, hanem egy köztes háború színtere, akkor a konfliktusrendszer feloldásához kisebb mértékben járulhat csak hozzá, és a megoldás elsősorban külső geopolitikai érdekek függvénye. Az ukrán belső átalakulás végeredményben mégis fontos tényező: a végkifejlet tekintetében rövid és középtávon is katalizátorként hathat a fajsúlyosabb horderejü, nagyhatalmi faktorok sodrásában. Amennyiben tehát jobboldali jelölt nyeri az elnökválasztást, úgy minden jel szerint a jelenlegi kemény álláspont érvényesül, és a biztonság „ára” magas marad - mindenki számára. Beleértve természetesen Magyarországot is: a magyar érdekek hatékonyabb érvényesülése, a biztonsági ráfordítások csökkentése csak egy enyhülés irányába elmozduló regionális környezetben képzelhetö el. Ennek kialakulásához nagyban hozzájárulhat egy kevésbé a szélsőségek felé tartó, mérsékeltebb programot preferáló jelölt győzelme az ukrán elnökválasztáson. 


\section{FELHASZNÁLT IRODALOM}

«В штабе Порошенко новая фантазия». Интервью Авакова - за минуту, [online], 2019. 02. 23. Forrás: Liga.net [2019. 03. 21.]

«Слава Україні!» у війську - що збентежило західних істориків?, [online], 2018. 08. 23. Forrás: Dw.com [2019. 04. 14.]

«Національні дружини»: що це за організація і чого вже встигла накоїти?, [online], 2018. 01 31. Forrás: Ictv.ua [2019. 04. 14.]

Kuzio, Taras: The Nation-Building Project in Ukraine and Identity: Toward a Consensus, [online], In: Kuzio, Taras - D’anieri, Paul (eds.): Dilemmas of State-led Nation Building in Ukraine, Praeger, London, 2002, 9-29. o. Forrás: Chtyvo.org.ua [2019. 04. 14.] DOI: https://doi.org/10.4324/9780203197592

LikHACHev, Vyacheslav: Far-right Extremism as a Threat to Ukrainian Democracy, [online], Forrás: Freedomhouse.org [2019. 04. 14.]

Summary of the Study „Extremism in Ukraine 2015-2016”, [online], 2016. 03. 03. Forrás: Uire.org.ua [2019. 04. 14.]

Ukraine: On patrol with the far-right National Militia - BBC Newsnight, [online], 2018. 04. Forrás: Youtube. com [2019. 04. 14.]

World-Low 9\% of Ukrainians Confident in Government, [online], 2019. 03. 21. Forrás: Gallup.com [2019. 03. 21.]

Аваков заявил, что у офиса Зеленского нашли прослушку: фото, [online], 2019. 03. 04. Forrás: Liga.net [2019. 04. 14.]

Виступ Петра Порошенка на Форумі «Від Крут до Брюсселя. Ми йдемо своїм шляхом», [online], 2019. 01. 29. Forrás: Youtube.com [2019. 03. 21.]

Горбулін, Володимир: Збройний конфлікт в Україні у термінах геополітики, [online], 2016. Forrás: Nbuv.gov.ua/ [2019. 03. 21.]

Гришин, В. И. - Кошкин, А. П. - Бочарников, И. В. - Черданцев, В. В.: Безопасность и интересы России в условиях украинского кризиса: анализ и прогнозы, [online], 2015, ФГБОУ ВПО «РЭУ им. Г. В. Плеханова». Forrás: Rea.ru [2019. 03. 21.]

Дмитрий БОБРИЦКИЙ: Она идет! 10 вещей со съезда Тимошенко, которые нас удивили, [online], 2019. 01. 23. Forrás: Liga.net [2019. 03. 21.]

Електоральні орієнтації та протестні настрої українців в активній фазі передвиборчої кампанії, [online], 2019. 03. 04. Forrás: Iap.org.ua [2019. 03. 21.]

За підтримку Заходу треба боротися щодня - президент, [online], 2018. 09. 20. Dzerkalo Nedeli. Forrás: Dt.ua [2019. 03. 21.]

Закон «Про освіту» прийнято - «за» проголосували 255 депутатів, [online], 2017. 09. 05. Forrás: Mon. gov.ua [2019. 04. 14.]

Закон України «Про освіту», [online]. Forrás: Zakon.rada.gov.ua [2019. 04. 14.]

Моніторинг електоральних настроїв українців. Лютий 2019, [online], 2019. 03. 04. Forrás: Ratinggroup. ua [2019. 03.21.]

НАТО солідарне з Угорщиною щодо українського закону про освіту, [online], 2019. 02. 26. Forrás: Dw.com [2019. 03. 21.]

Новий економічний курс України. Презентація програми, [online], 2018. 09. Forrás: Nku.com.ua [2019. 04. 14.]

Новий економічний курс України. Стратегія інноваційного розвитку, [online], 2018. Forrás: Nku.com. ua [2019. 04. 14.]

Новий курс України. Нові можливості для кожного, [online], 2019. Forrás: Liga.net [2019. 03. 21.]

Обращение президента России В. В. Путина 18 марта 2014 года к обеим палатам Федерального собрания, [online], 2014. 04. 18. Forrás: Kremlin.ru [2019. 03. 21.]

Полиция расследует раздачу денег избирателям в офисе депутата БПП, [online], 2019. 02. 23. Forrás: Liga.net [2019. 04. 14.]

Порошенко підписав закон про статус учасника бойових дій для ветеранів УПА й ОУН, [online], 2018. 08. 23. Forrás: Dw.com [2019. 04. 14.] 
Правила кандидатства Юлии Тимошенко, [online], 2019. Forrás: Liga.net [2019. 03. 21.]

Про відзначення пам’ятних дат і ювілеїв у 2019 році, [online]. Forrás: Zakon.rada.gov.ua [2019. 04. 14.]

Програма політичної партії «Громадянська позиція», [online], 2018. Forrás: Rea.ru [2019. 03. 21.]

Раді пропонують присвоїти Степану Бандері звання Героя України, [online], 2018. 12. 05. Forrás: Interfax.com.ua [2019. 04. 14.]

Рівень довіри до суспільних інститутів та електоральні орієнтації громадян України, [online], 2019. 02. 20. Forrás: Razumkov.org.ua [2019. 03. 21.]

Романюк, Роман: Коррозии государсва. Куда нас заведет активность «правых», [online], 2018. 08. 10. Forrás: Pravda.com.ua [2019. 04. 14.]

Смирнов, Юрий: Заживем по-людски. Как топ-кандидаты обещают поднять экономику, [online], 2019. 02. 14. Forrás: Liga.net [2019. 03. 21.]

Смирнов, Юрий: Казнить взяточников! Как топ-кандидаты обещают побороть коррупцию, [online], 2019. 02. 07. Forrás: Liga.net [2019. 03. 21.]

Супрун, Роман: Поделить и под суд: как кандидаты в президенты видят реформу Рады, [online], 2019. 02. 21. Forrás: Liga.net [2019. 03. 21.]

Тимошенко назвала СБУ „провокаторами на содержании Roshen”, [online], 2019. 02. 22. Forrás: Liga.net [2019. 04. 14.]

Тимошенко похвалила Авакова: Фальсификаций и подкупа не будет, [online], 2019. 02. 22. Forrás: Liga. net [2019. 04. 14.]

Україна на передодні президентських виборів 2019 - лютий, [online], 2019. 02. Forrás: Socis.kiev.ua [2019. 03.21.]

Урочистий з’їзд Всеукраїнського об’єднання «Батьківщина» [online], 2019. 01. 22. Forrás: Liga.net [2019. 03. 21.]

Шрамович, В’ячеслав: «Національні дружини”: хто і навіщо їх створив, [online], 2018. 01. 30. Forrás: BBC [2019. 04. 14.] 